Etnográfica

Revista do Centro em Rede de Investigação em

Antropologia

vol. 22 (1) | 2018

Vol. $22(1)$

\title{
To repay or not to repay: financial vulnerability among mortgage debtors in Spain
}

Pagar ou não pagar a dívida: vulnerabilidade financeira entre os devedores de crédito para compra de habitação em Espanha

Irene Sabaté Muriel

\section{(2) OpenEdition}

Journals

Electronic version

URL: https://journals.openedition.org/etnografica/5130

DOI: 10.4000/etnografica.5130

ISSN: 2182-2891

\section{Publisher}

Centro em Rede de Investigação em Antropologia

\section{Printed version}

Date of publication: 1 February 2018

Number of pages: 5-26

ISSN: 0873-6561

Electronic reference

Irene Sabaté Muriel, "To repay or not to repay: financial vulnerability among mortgage debtors in Spain", Etnográfica [Online], vol. 22 (1) | 2018, Online since 17 May 2018, connection on 20 January 2022. URL: http://journals.openedition.org/etnografica/5130 ; DOl: https://doi.org/10.4000/ etnografica. 5130

\section{(c) (;) (9)}

Etnográfica is licensed under a Creative Commons Attribution-NonCommercial 4.0 International License. 


\section{To repay or not to repay: financial vulnerability among mortgage debtors in Spain}

\section{Irene Sabaté}

In the framework of the current wave of home repossessions, many Spanish households struggle to keep up with repayments before going into arrears. Their financial vulnerability is not a simple function of the availability of income as they are repaying debts. Rather, it is to be understood in combination with a differential access to other resources that may help households to cope with hardship. Factors that help to keep up with repayments may include the availability of material aid and non-economic resources, such as information or social connections. But, at a certain stage, debtors may benefit less from aid to keep up with repayments, than from the advice to give them up, a decision that implies challenging the moral obligation to repay and devoting much time and effort to negotiation with the creditor. The availability of these resources needs to be considered in order to understand the (re)production of social inequalities linked to financial vulnerability as a result of mortgage default.

KEYWORDS: mortgages, indebtedness, financial vulnerability, home repossessions, social inequality, Barcelona.

Pagar ou não pagar a dívida: vulnerabilidade financeira entre os devedores de crédito para compra de habitação em Espanha No quadro da vaga atual de execução de hipotecas de casas, muitas famílias espanholas fazem grande esforço para pagar a tempo as prestações de empréstimos contraídos para a compra de habitação, tentando não entrar em incumprimento. A sua vulnerabilidade financeira não é mera função do rendimento de que dispõem quando têm dívidas a pagar e deve ser entendida em combinação com o acesso diferenciado a outros recursos que poderão ajudá-las a fazer face às dificuldades. Entre os fatores que facilitam o pagamento das dívidas poderão estar a disponibilidade de ajuda material e recursos não económicos, como a informação ou as relações sociais. Porém, a um certo nível, o mais vantajoso para os endividados pode não ser a ajuda para cumprirem com os pagamentos, mas sim o conselho de que deixem de pagar as prestações, uma decisão que implica pôr em causa a obrigação moral do pagamento da dívida e dedicar muito tempo e esforços à negociação com o credor. A disponibilidade desses recursos deve ser considerada para se compreender a (re)produção das desigualdades sociais ligadas à vulnerabilidade financeira resultante do incumprimento no pagamento dos empréstimos.

PALAVRAS-CHAVE: crédito à habitação, endividamento, vulnerabilidade financeira, penhoras bancárias, desigualdade social, Barcelona.

SABATÉ, Irene (sabate.irene@gmail.com) - Departament d'Antropologia Social, Universitat de Barcelona, Spain. 
WHEN MORTGAGE INDEBTEDNESS LEADS

TO FINANCIAL VULNERABILITY

In the last years, over-indebtedness due to mortgage loans has been perceived as one of the main threats for the reproduction of impoverished Spanish households in the context of the current economic crisis. ${ }^{1}$ This perception, now widely shared across Spanish society, is consistent with statistical data: more than 730,000 home repossessions were initiated between 2007 and the first trimester of 2017. ${ }^{2}$ Many of these legal processes have affected first residences, leaving families homeless and heavily indebted beyond the eviction, due to the particularities of the Spanish mortgage law (Nasarre 2011; Colau and Alemany 2012; Valiño 2014): after the auction of the housing unit, debtors are held responsible for the difference between their outstanding debt and the lower price paid by the bidder.

However, what is now perceived as an unsustainable situation and, therefore, is frequently labelled as over-indebtedness, was not considered as such when mortgages were taken out. Indeed, during the years of prosperity, getting indebted was perceived as the normative strategy in order to access home ownership (Garcés and Salcedo 2008: 20), the most popular and desirable form of housing tenure for most Spanish households (Naredo and Montiel 2011; Allen et al. 2004; López and Rodríguez 2010), including a first generation of non-European migrants (Terrones 2013; Palomera 2014a; Suárez 2014). The availability of credit - even for the most vulnerable social sectors, who constituted a sub-prime market fostered by national and international financial interests (Aalbers 2008; Nasarre 2014) - contributed to a general atmosphere where the risk of insolvency tended to be downplayed, even if many jobs were temporary and income was highly dependent on unstable economic conditions, such as the availability of overtime work. That was, for instance, the case of one of our informants, Vanessa, a private security agent and single mother of two, who relied on working overtime to cope with her mortgage repayments. As the economic crisis began to affect her company and that possibility was no longer available, she was forced to accept a night job in order to supplement her main wage. Another typical case was that of people directly or indirectly involved in the booming building sector, like another of our informants, Juan, who, according to his wife Mayte, "had a lot of work on the construction site,

I This research was supported by: Wenner-Gren Foundation (Post-PhD Grant 2014); Catalan Government (AGAUR, SGR 2014); Ministerio de Economía y Competitividad y Fondo Europeo de Desarrollo Regional (FEDER) (project: "Concepciones populares de la justicia social ante la crisis y las políticas de austeridad" [CSO2015-67368-P], coordinated by Mikel Aramburu Otazu and Sílvia Bofill Poch, 2016-2018).

2 Data provided by the Spanish General Judiciary Council (Consejo General del Poder Judicial). 
he got home every day at nine in the evening, he worked overtime, was really busy, he sometimes supervised two construction sites at a time."

Under those circumstances, credit institutions were depicted as contributors to the general prosperity of the country, as well as sponsors of households' projects of material improvement, importantly concerning housing conditions. The irresponsibility of widespread practices involved in mortgage lending (Nasarre 2011; Zunzunegui 2013), including predatory lending and sub-prime mortgages, would not become visible until the advent of the crisis, when the most vulnerable sectors of society were the first to fall.

The most common attempts at defining the notions of over-indebtedness (European Commission 2008; Dubois and Anderson 2010; Fondeville, Özdemir and Ward 2010) tend to focus on objective indicators, such as the proportion of household income assigned to mortgage repayments or the percentage of the value of the housing unit that is covered by the mortgage. Normative statements are established in this regard: typically, it is stated that repayments should not exceed $30 \%$ of income, and that mortgages should not exceed $80 \%$ of the total value of the housing unit. ${ }^{3}$ Such statements are made irrespective of the fact that few credit institutions observed such norms in assessing the eligibility of customers as mortgage borrowers, and that the loose legal regulation of mortgage lending did not encourage caution either on the borrowers' or the lenders' part (Nasarre 2011; Zunzunegui 2013). These quantitative measures of over-indebtedness point at potential difficulties that households could face.

In other cases, situations of over-indebtedness are identified in hindsight, when debtors are already in default or about to reach that condition (European Commission 2008), usually as a result of a steep, unexpected decrease of income derived from unemployment, underemployment or other adverse circumstances such as illness, disability, the breakup of marital relationships, and the like. Under such circumstances, households find themselves unable to cope with mortgage repayments - usually among other financial commitments, such as the payment of energy bills - and can therefore be objectively described as over-indebted.

At that point, debtors are forced to negotiate with banks. Such negotiations often lead to debt restructuring arrangements or to the concession of a waiting period in exchange for harsher repayment conditions - increased interest rates or longer repayment periods, for example - in the framework of refinancing or forbearance schemes (Stout 2015; Langley 2009). But these

3 The standard (repayments not exceeding 30\% of the income) for housing affordability is now widely accepted after its adoption in several Anglo-Saxon countries, such as the US or Australia, during the 1990s. Some sources prescribe it to the population placed in the lower $40 \%$ of income distribution. See, for instance, the 2007 report of the Australian Housing and Urban Research Institute (Yates and Milligan 2007). 
supposed advantages rarely prevent debtors from getting trapped in unsustainable situations, with their debts increasing every month due to late payment interest. Thus, for example, Esteban, an electrician and father of two who had to quit his job as a result of his cardiac illness, found himself owing the whole $€ 390,000$ he had borrowed at first, despite the fact that he and his wife had been doing great efforts in order to meet their financial obligations for several years, managing to repay € 140,000 . In addition, in more political terms, debt refinancing or forbearance does not make a difference regarding debtor-creditor relations, as it does not redefine their respective responsibilities, and, therefore, closes down any possibility to challenge the interests of the credit industry, in terms of reclaiming a "coresponsibility between lender and borrower" (Langley 2009: 1411). Indeed, Spanish mortgage debtors appear at first sight as the incarnation of Lazzarato's "indebted man" (201 1), subject to the rule of debt on their lives, perpetually condemned to devote the product of their present and future labour to loan repayments. According to Ross (2014), the rule of debt on indebted subjects can only be counteracted or even neutralized by their conscious option for debt refusal. Drawing on his description of incipient popular movements against widespread indebtedness in American society, Ross contends that the refusal to repay debts has an emancipatory potential, as it subverts the order of finance capitalism, based on the domination of a creditor class over a debtor class: what he calls a "creditocracy."

But, what are the conditions of possibility of the refusal of debt obligations on the part of debtors? In this article, it is our contention that the subjective perception of over-indebtedness - rather than an attempted objective definition of it as a result of a lack of proportionality between a household's income and its financial obligations - is a crucial factor that contributes to trigger the disobedience of indebted households to the rule of debt. In order to address this contribution, we need to depart from the self-perception of borrowers concerning their indebtedness, that is to say, from "households" perceptions about the influence of mortgage repayments and housing costs in particular, on their financial situation more generally" (Georgarakos, Lojschova and Ward-Warmedinger 2010: 15). This conceptual possibility, connected to the wider notion of financial vulnerability, fits our purpose better than any objective or quantitative definition of over-indebtedness, as it acknowledges the importance of the subjective experience, of the assessment of the available resources - economic and non-economic -, and of social actors' planning and decision-making while coping with the mortgage crisis.

As it will be described in the following sections, mortgage debtors tend to prioritise mortgage repayments over other expenses, and typically make a variety of efforts to mobilise resources - both economic and non-economic - in order to keep up with their financial commitments. But, in some cases, they may reach a situation where the obligation to repay itself is reconsidered, be it 
because of debtors' absolute inability, be it because of the certainty that such inability will emerge in the short term.

What is, then, the connection between the experience of over-indebtedness and financial vulnerability, the strategies to cope with difficulties to repay, and the eventual decision to quit repayments? Drawing on ethnographic findings collected in the metropolitan area of Barcelona between 2012 and 2015, a strong interconnection among the three aspects will be pointed out. ${ }^{4}$ Both the sequence and the pace of events, however, may vary from case to case, depending, among other factors, on the pressures that the social obligation to repay debts exerts in each situation, as well as on the influence of counter-hegemonic discourses about the illegitimacy of mortgage debts. It will be contended that such variations can ultimately either reproduce or qualify patterns of inequality in the era of finance capitalism.

\section{FACTORS OF FINANCIAL VULNERABILITY}

As we have seen, an inadequate relation between household income and the combination of financial commitments that need to be fulfilled can lead borrowers to financial vulnerability. Indeed, mortgage repayments play a crucial role in such situations, both because of their amount and because of the centrality of housing provision in people's livelihoods. The ghost of homelessness accounts for people's prioritisation of mortgage repayments over other basic expenses. This is so even in the cases where debtors can be certain that they are going to be in arrears in a few months' time. For Esmeralda, an unemployed hairdresser who is currently struggling to prevent her bank from repossessing both her first and second residences, this prioritization of mortgage repayments over other needs is a mistake made at first by most mortgage debtors, while they are still denying the fact that their adverse economic situation has a permanent nature. Esmeralda's account matches the one offered by Salvador, a private security agent who faces the repossession of his flat and that of his parents-in-law, both placed in a peripheral, working-class neighbourhood:

"We had to cut our expenses. Months before giving up our efforts to keep up with mortgage repayments, we sold all our possessions: jewels, gold, a ring that had belonged to my wife's grandfather... A wedding ring. My

4 This article is based on ethnographic research carried out in the metropolitan area of Barcelona between 2012 and 2015. This included interviews and observation among mortgagors vulnerable to repossessions, as well as other actors involved in the mortgage crisis, including anti-repossession activists, representatives of third-sector organisations, state officials and policymakers, and a wide variety of professionals currently or formerly involved in the mortgage business (economic experts, bankers, real-estate agents, money lenders, investors, lawyers...). 
grandfather's chain. We sold everything. Let's see whether things are better next month, let's try hard... And then you realise that everything has been in vain."

It has been commonplace in mainstream narratives of the crisis to blame the lower and middle classes to have lived over their means during the years of the housing bubble, pursuing a rapid improvement of material living conditions through indebtedness, while trusting the never-ending revaluation of properties. ${ }^{5}$ However, several aspects beyond households' individual practices of consumption and credit borrowing deserve our attention due to their structural nature.

First, in the realm of social representations about the economy, the belief that nothing threatened the Spanish prosperity, and the trust on a never-ending era of growth, where real-estate prices would never stop increasing, was widespread in society, and actively promoted by political and economic elites (Naredo 2009; Torres 2010). This atmosphere fuelled expectations of upward social mobility and of material improvement among wide sectors of the working and middle classes. People at different stages of their life cycles decided to purchase housing units as a strategy to start a family, to upgrade their living conditions, to build a heritage for the next generation, or to make a profitable investment a few years before retirement. Esteban's decision to buy a large flat in his own neighbourhood - a gentrifying area of Barcelona - and to eagerly remodel it himself, after being a tenant for several decades, was largely inspired by such optimistic aspirations, at a moment where his business seemed prosperous, his health problems had not appeared yet, his wife did not need to work more than part-time at a gym, and their two daughters pursued their secondary and higher education relying on the parents' support.

In addition to this symbolic dimension, a whole structure of incentives for home ownership was in place, including tax advantages and other public policies. Such incentives pushed wide layers of the Spanish society, including the working classes and recently arrived migrants, into the condition of home-owners - and of mortgage debtors (López and Rodríguez 2010; Naredo and Montiel 2011; Palomera 2014a). Indeed, under such circumstances, purchasing a home by means of a mortgage seemed a sensible decision, in contrast with the poor conditions and the instability offered by the rental market. This was, for example, the reasoning that led Vanessa to buy her apartment: "Since my divorce in 1999, I had always rented, and then I thought, I am paying 800 euros, for a little more - and I was earning 2000 euros back then -, I can go for home-ownership. After all, it would be for me and for my daughters' future."

5 This argument was the first of the " 11 myths about the crisis" deconstructed by the Cátedra de Finanzas Solidarias y Desarrollo Humano in their website, <www.eii.uva.es/mitos/mitos/mito l.htm > (last access in February 2018). 
As it can be noted in her words, the risks of mortgage indebtedness were veiled by the apparent advantages that emerged from a rational - though simplified - comparison between two possible forms of tenancy, renting and owner-occupation.

As a third set of factors that help explain the mass access to home-ownership by the Spanish population, banks and real-estate professionals developed aggressive commercial strategies, some of them fraudulent and others simply taking profit of the weak regulation of the financial and real-estate markets, in order to further expand market niches (Nasarre 2011; Zunzunegui 2013). Potential customers were chased by mortgage brokers and bank employees through a variety of strategies according to a segmentation based on credit scoring and measures of financial solvency (Torres 2010: 72-73). In some cases, for example, they were encouraged to borrow the whole amount of the flat's price, or even a percentage over 100\%, in order to cover further expenses, such as the purchase of furniture or cars, refurbishments, or paperwork and notary fees. These offerings were often embraced by people who saw them as an opportunity to improve their material living standards, while others, like our interviewees Mayte and Juan, rejected them as an unnecessary risk:

"J The mortgage was 100\% [of the flat's price] because we said we didn't want more. The bank gave us more.

M I said, let us cover the notary's fee, and that's it.

J They told me, come on, you can buy a car, you are always driving around. But I already had a car.

M And for the refurbishing, with the amount that we obtained with the other flat, and the sale of a boat we had... I refurbished the kitchen with that, you know? We didn't ask for more.

J Even if they would have lent it to us.

M I was amazed at that... But we will not be able to repay it! We were cautious about that. We did not borrow more than what was necessary. And, even so, we got in trouble. Imagine those who had asked for more."

Borrowers were often provided with incomplete or misleading information, as brokers over-emphasized the stability of repayments irrespective of uncontrollable circumstances - such as rising interest rates or decreasing housing prices -, and avoided to warn them about other expenses connected to their mortgage, such as insurances, unexpected fees, taxes, major repair expenses, and the like. In addition, customers with certain profiles - especially migrant workers -were forced to provide the names of other people - relatives, friends, acquaintances, and even strangers in some cases - who accepted to act as guarantors of their mortgage contracts (Terrones 2013; Suárez 2014). In this way, 
whole social networks within the weakest sectors of population were collectively trapped in mortgage over-indebtedness and threatened by the potential risk of default.

In this context, not many actors were in the position to forecast what came next, nor to actually identify the dangers mortgage borrowers were exposed to since they signed their mortgage contracts. Behind the technicalities of intricate legal clauses, whose actual understanding was unachievable for most of the population, hid the very factors of vulnerability that, in many cases, would be traumatically unveiled as soon as mortgages went into arrears. Indeed, longterm unemployment or underemployment was not perceived as a real threat, as temporary jobs seemed to be always available, wages were stable or rising in some cases, and the possibility to work overtime or to combine several jobs in order to significantly increase income was a popular strategy in many employment sectors. The list of overlooked risks and vulnerabilities includes thus the termination of temporary job contracts, dropping wages, and the sudden unavailability of extra sources of income. Besides, other reasons for a potential drop in income were also ignored, such as the inability to work through sickness and disability, periods of parental leave, the transition to retirement, or changes in household composition due to marriage breakdown among other life cycle circumstances (Eurostat 2012).

All these unexpected circumstances have revealed that many households who suddenly faced the threat of repossession had become over-indebted as soon as they had borrowed their mortgage loans. This condition, however, had not been averted because the context in which they had signed their contracts was radically different from the context they found themselves in at present. The significance of such changes has led some progressive judges to argue that a Roman Law principle, rebus sic stantibus - "things standing thus," meaning that contracts must be fulfilled as long as the circumstances under which they were signed are not significantly changed - could be applied in order to force a renegotiation of repayment conditions, or even to claim for the forgiveness of mortgage debts. ${ }^{6}$

But, despite the strong determinations implied by the structural nature of the crisis, the rapid impoverishment of wide social sectors should not be understood as a catastrophe passively experienced by working-class and middle-class households. Rather, it should be addressed in combination with

6 In fact, there is a controversy among the progressive sector judges on this issue: while one of our interviewees, Diego Gutiérrez from the Court of Lleida, supported a sentence by one of his colleagues in Palma de Mallorca and pointed at the rebus sic stantibus doctrine as a possible solution for unpayable debts, another judge we interviewed, Guillem Solé, from the Court of Barcelona, expressed his doubts about its applicability to the particular case of mortgages. For Solé, the doctrine only applies to contracts in which both parts are acting simultaneously, but in this case banks already fulfilled their commitment - to provide the loan - as soon as the contract was signed. 
people's active role in the mobilisation of economic resources other than income. Informal social relations, such as kinship ties, have made possible the circulation of crucial economic support, in order to soften both the objective disproportion between income and expenses, and the subjective perception of over-indebtedness. Besides, although no doubt to a lesser extent, assistance from the State or from charities can also be obtained, either in monetary form - financial aid to pay mortgage arrears or energy bills - or in kind - for instance the provision of food or clothes. As a result, financial vulnerability is also influenced by factors such as the inclusion in mutual support networks, and the eligibility for welfare and charity provision (Sabaté 2014).

The mechanisms for the mobilisation of non-economic resources should also be taken into account. These broadly include the use of pertinent social connections, the access to expert knowledge, for example concerning legal aspects of contracts or of the process of home repossession itself, as well as the skills needed to cope with bureaucracies and to negotiate with credit institutions (Bourdieu 2001; Sabaté 2016). According to our ethnographic material, this ability to mobilise non-economic resources, that can be encompassed by the notions of social and cultural capital (Bourdieu 1979, 1980), is a distinctive feature of the least vulnerable borrowers, whose initial situation contrasted with that of households lacking connections and information. Gloria's experience is a conspicuous example of such disadvantaged position: a migrant from Peru, a victim of domestic violence by her Spanish husband, and a self-standing trader in a very precarious economic situation, her siblings persuaded her to purchase a flat as an investment for the future. Finally separated from her husband, evicted from her flat, heavily indebted, psychologically troubled, precariously accommodated in a rented room, unemployed and with no access to public subsidies, she had to struggle for the forgiveness of her debt, and of those incurred by several of her siblings who had gone back to Peru, in front of a bank and a legal system that she hardly understood. Her dramatic story contrasts to a certain extent with others, such as for example Mayte and Juan's, who receive the support of their parents in the form of daily meals, childcare and occasional aid with medical expenses, or Esteban's, whose desperation has not led him so far to ask his children to quit university, as this would entail to deny them a future, and who reports to have acquired, out of necessity, a considerable technical knowledge concerning his legal and economic situation.

Esteban's case, alongside other debtors', also illustrates how, most interestingly, social and cultural capital should not be seen as a fixed asset owned by particular households or individuals. Rather, such factors are always in the making, as new circumstances are met: there is at least some room for empowerment in this sense. The example of many members of the main social movement that has emerged as a response to the mortgage crisis, the Plataforma de Afectados 
por la Hipoteca (PAH), who have become real experts in their economic and legal situations despite their initial lay condition and their lack of activist background, is an excellent illustration of the plasticity of non-monetary resources. ${ }^{7}$ Thus, as we first met Junior in an assembly of the local PAH, he was a disoriented young man who desperately sought an exit for the mortgage default situation his parents found themselves in. Some months later, he had devised a whole strategy to put pressure on the director of their bank branch, including sharp arguments about the fraudulent circumstances in which his father had accepted the conditions of the mortgage, and a deep knowledge of the potential consequences of his own actions while claiming for the assignment in payment, that is to say, for the total cancellation of the mortgage debt in exchange for the flat. Many other informants, like Vanessa, also describe their experience of feeling empowered through their participation in the movement:

"Some days ago I went to a negotiation with another member, I volunteered to go with her, and look what must have come out of my mouth, I was shaking afterwards, and even the bank director told me, you must be the PAH's lawyer. And I said, no, I am not a lawyer, I just have very good advice. I don't know what I said... That is the strength the PAH gives us."

The same kind of anecdote is evoked by many mortgage debtors whose commitment with the anti-repossession movement helps them emerge as an active, self-conscious and belligerent part in their struggle with credit institutions, getting over their previous state of isolation, shame and disorientation (Colau and Alemany 2012; Mangot 2013; Mir et al. 2013).

In this section, it has been our contention that the combination of two sets of factors - potential drops in income and increases in the amount of repayments, plus the mobilisation of economic and non-economic resources accounts for the particular situation of each household and for their chances to overcome financial vulnerability associated to mortgage-related over-indebtedness. Let us now consider what this resilience may consist in: either in managing to keep up with repayments, or in giving them up and overtly assuming the condition of mortgage defaulters.

\section{TO REPAY... OR NOT TO REPAY}

We have so far stressed the heterogeneity of mortgage-related over-indebtedness situations due to the combination of several factors of financial vulnerability. Furthermore, as we have also contended, the self-perception of domestic 
economies in front of their mortgage debt, that will eventually inspire their everyday economic action and their coping strategies in the face of repossession processes, is not simply determined by their socio-economic position or by any other objective conditions such as the ratio between income and debts or expenses. On the contrary, the perception of the situation, for instance as a sustainable or unsustainable one, will depend on subjective evaluations that will in turn influence the prioritisation of needs and expenses. For example, Mayte stressed that she did not feel the need to resource to social welfare institutions or to charities. She rather relied on kin support, for example by having her family - the couple and three children - eating one daily meal at her parents-in-law's. This is so despite the fact that, recently, other relatives - her sister and brother-in-law - are also being threatened by over-indebtedness, and therefore are in need of support too. During our first conversation, she repeatedly expressed how lucky she felt to be supported by the previous generation - a possibility that was not available for other people she knew, for example a neighbour of hers with a migrant background. A while later, however, she felt the need to clarify that her relatives' socio-economic situation was also a very humble one, as they only counted on their retirement pensions, and that, even if they would not question their duty to support Mayte's family, doing so required big efforts on their part. Still, Mayte and her husband did not perceive their situation as requiring the provision of public welfare or of charitable aid.

A particularly interesting process is the one that leads a household to depict their own situation as unsustainable, and therefore to decide to quit repayments. Such decision may be made sooner or later depending on the case, on the access to different kinds of expert advice and on the degree of engagement with social movements such as the PAH. But, before focusing on this issue, let us consider what typically occurs at the beginning of the repossession process - or immediately before that moment.

In some cases, the strong commitment to fulfil mortgage obligations leads those borrowers unable to cope with whole repayments to transfer lower quantities to the credit institution, hoping that this behaviour will be interpreted as a sign of goodwill, and that the access to new sources of income will allow them to regularise the situation as soon as possible. The fact is, nevertheless, that such incomplete repayments do not prevent the home repossession process from being started by the bank. Whenever this happens, borrowers find out that the sacrifices made in order to show their intention to repay had been in fact useless: they are often struck by the revelation that the money they have been transferring for months is lost, and that it does not make any difference in the creditor's eyes. Indeed, during the assemblies of the PAH, a typical scene was repeated over and over as new participants introduced themselves and explained how they were struggling to pay "what they could" every month. The unanimous answer of the assembly was always to urge them to 
quit repaying, as they were "throwing away" the money they had been gathering with great efforts. Proofs of "good faith," they said, are not taken into account by banks. Esmeralda was one of the people who repeatedly advised to quit repayments: “The bank doesn't care whether you owe them 110285 euros, or 110000 euros. They don't care, and you will be able to eat that month, or to buy sports shoes for your kids."

It is also common that mortgage borrowers who anticipate problems to repay - for example as a result of the termination of their employment contract, the end of unemployment benefits or the exhaustion of their savings - address themselves to their banks in search for a renegotiation of the mortgage's conditions. It is usually at that point that they perceive a radical change in the way bank clerks treat them. They have lost the condition of customers who used to be welcome in the bank branch, and start to be treated as an annoyance or a problem. This is what Esteban felt when he had to deal with bank employees:

"It is difficult to negotiate with them, they don't have any sentiments and don't care about you. Whatever your situation is. Then, as you talk to them, they show an arrogant attitude, as you cannot repay you are no one, and then you suffer a lot because you have to endure their nonsense and insolence. And this makes you feel very aggressive. You have to control yourself because they have been bailed out $[\ldots]$ but they blame you because you are in arrears."

At that stage, as it has been described, debtors are systematically offered either a restructuring of the loan - in exchange for increased interests and/or a longer repayment period - or a waiting period during which repayments are temporarily suspended. In both cases, borrowers tend to accept the bank's conditions as they allow an adjournment of pressures, in the hope of being able to focus on more urgent needs in the short term, and of having their income increased in the near future, mainly by finding a job. During the first years of the crisis, it was typical for debtors to disregard the fact that, if such increase of income did not come true, their situation would be aggravated thereafter. In view of this, the advice of PAH assemblies is that no restructuring of mortgage debts should be accepted if it entails a future aggravation of the indebtedness situation based on the motto "feast today, famine tomorrow." 8

8 "Pan para hoy, hambre para mañana," meaning that what today seems an attractive opportunity will entail an aggravation of the problem in the future. This attitude promoted by the PAH contrasts with the approach of other actors mediating in mortgage default situations, such as the Catholic organisation Caritas, whose mediation services, instead of promoting the active refusal to repay, often support refinancing schemes offered by banks, in the hope that debtors will be able to improve their situation in the mid run, while, in the meantime, they should avoid at all costs being in arrears. 
However, debtors' eagerness to accept refinancing schemes regardless of their future consequences can be understood in the light of the acute suffering provoked by their situation, as well as of the pressures that banks and society at large put on debtors. Indeed, several of our informants reported how, as debtors in hardship, they may be eager to accept anything that alleviates their present suffering. This adds to the fact that their precarious situation prevents them from planning or forecasting their future, which makes them feel defenceless, as Esmeralda explained: "You learn not to make any plans, because there is no point. You give up planning your life, thinking about tomorrow. Not only about next month. You cannot think, if you think about tomorrow you go mad."

Besides, bank clerks themselves are interested in fostering refinancing schemes in order to avoid their growing default figures: a refinanced mortgage does not stand as default in the bank's balance sheets. This also contributes to explain the harassment to which debtors in arrears may be exposed, as we can see in Mayte's experience:

"They call you describing everything so nicely, and trying to convince you. You are not sure about what you're going to do. They were cheating all the time. They called me and told me something. They called my husband and told him something else... They made us argue: your wife has told us that you will come to sign tomorrow. And my husband said, my wife has not said that... They wanted to make us sign for the waiting period."

Usually after the first events already described, perhaps after a bad experience with a refinancing scheme, the possibility to completely quit repayments starts to become thinkable. Of course this does not happen immediately: for most mortgage debtors, not to repay is really the last path to be explored. Indeed, the obligation to repay debts (Mauss 1979 [1923-24]; Graeber 201 1), and particularly to repay mortgage debts, remains among the most widely shared social norms governing economic behaviour in our society. Defaulters are strongly stigmatised due to their alleged irresponsibility (Stout 2016; Jefferson 2013), or even by the supposed advantage to enjoy something - a home - without paying for it. Even debtors who strongly justify their decision to quit repayments may feel the need to assert their "good faith" and to argue that they had no choice, but that their decision still causes them discomfort, as they do not identify themselves with the social representation of mortgage defaulters. For instance, Ramon, a former businessman whose economic troubles have led him to depression and to an attempt to commit suicide while facing his home repossession, is strongly reluctant to accept the label of mortgage defaulter: 
"I am not a professional defaulter, I have become insolvent due to the circumstances of life, you know? If I had liquidated my firm in another moment and I had been able to replace it with a job, I would have been able to keep up with repayments, but now I don't have this possibility."

As such situations are the cause of much fear and shame, of suffering and of a sense of failure, they are sometimes kept in secret and endured in isolation. For instance, Esteban asserts his determination to minimize his daughters' suffering by providing them only with the indispensable information; Juan is strongly determined to hide the repossession threat to his two younger children, and Vanessa has been postponing the moment when she will be forced to tell her sister that their elderly parents are at risk of losing their home because they accepted to be the guarantors of their daughter's mortgage. Of course this is not always so: sometimes the news circulate through social bonds, or even, among the most politicised members of anti-repossession movements, the decision to quit repayments is made public as part of deliberate strategies of visibilisation. Esteban describes his own evolution in this sense:

"I always hid a bit, because of my customers, it was better that they didn't know because otherwise they would have taken advantage [...]. But now I don't care anymore, if I have to participate in a mobilisation and I am on TV, I am on TV, that's it. And if I have to be interviewed, whatever it takes. I don't care. Because this has to be unveiled and everybody has to learn about it, about what is happening. There is no need to hide it."

Common to most cases is, anyway, the salience of the decision to quit repayments in the longer experience of the repossession process. It tends to be followed by a double sentiment of loss: defaulting borrowers do not only renounce to their home, a crucial aspect of their future projections as well as a central resource of their livelihoods, but also to all the money invested in repayments up to that moment, usually by means of great efforts and sacrifices, especially during the last months or years. Sonia, an unemployed shop assistant who recently obtained her assignment in payment and therefore got free of her debt after losing her home, expressed this sentiment of loss despite her victory in front of the bank:

"All your dreams go fuck themselves... [...] When you buy a flat, you think it will be your home forever, don't you? You choose every tiny detail with great love, and now you know that it will not be respected by whoever comes, everything that took you such great effort." 
In addition, the loss of the property also entails the loss of the home-owner condition, and this can be experienced as a step back in one's life course. That was the case of Nelson, Junior's father. As he narrated the day he no longer had his flat, he described the same feeling he had when, 15 years earlier, he arrived from Ecuador as a young migrant who had to look for a job and a room to rent.

At the same time, a sense of guilt may be reinforced when the debtors' social environment blames them for their failure to repay. In Vanessa's case, even if her parents agreed to accommodate her and her daughters as they lost their home, she has to deal with their reproofs during their daily cohabitation, as they do not approve her decision to quit repaying her mortgage. As for Mayte's mother and in-laws, even if there is no overt conflict in their everyday contacts, frequent comments are made concerning how easier things would be if they had not taken the risk of moving to a bigger flat.

But, despite blaming and self-blaming processes, a shift in attributions of responsibility may also occur: defaulting mortgage borrowers may now feel that banks and politicians - and to a lesser extent other social actors involved in the real-estate and financial business - are to blame instead of themselves. Salvador argued for this re-attribution of responsibilities:

"You open your eyes and say, I am not the only one to blame, I haven't done this all alone, yes, I signed, but I was not warned about this and that. And then you realize about their [the bank's] outrages [...]. Yes, I signed, but you knew what I was signing. You agreed and you have grown rich with appraisals, with everything [...]. It is not illegal, but it is immoral."

Of course, the emergence of anti-repossession movements representing the interests of mortgage debtors and stressing the structural dimensions of the mortgage crisis accounts for this to a great extent. The most prominent movement, the PAH, has promoted the conversion of mortgage debtors into a significant social and political actor in the public sphere. Their prior stigmatisation and invisibilisation has been overcome to a great extent, thanks to several audacious campaigns that, by identifying the common interests and circumstances of mortgage defaulters in different socio-economic positions, have consolidated an alternative narrative of the mortgage crisis (Mangot 2013; Mir et al. 2013; Sabaté 2014; García-Lamarca and Kaika 2016). Ada Colau and Adrià Alemany (2012: 71 ), two of the founders of the PAH, have summarized this task as follows:

"The first goal of the PAH is to generate spaces of trust and community in the meetings, where people are given the opportunity to express themselves and to share their experience with others. To build this space and to bring together personal experiences will be crucial so that those affected by 
mortgages realize about the collective dimension of the problem, and about the fact that there are structural factors that influence our decisions. The process of exoneration is a necessary step, prior to empowerment."

As described above, the pace of events in the face of repossessions strongly varies. In many cases, the decision to stop repaying is made in the last minute, as a result of the absolute inability to meet the next repayment, or even in the face of the first arrears, when the expectation to be able to settle the outstanding amount is eventually discarded. But, other times, the decision to quit repaying is anticipated, then communicated to bank clerks, and perhaps profusely justified. This may happen with relative independence from the pressures of the moment. The decision may be rationalised as the wisest move in the face of the unsustainability of the situation in a few months' prospect. Of all financial obligations, mortgage payments may be then seen as the most unsustainable one, due to their amount and to the length of the repayment period. As Esteban put it,

"What we don't like is failing to repay things. Mortgage repayments are a big amount of money, otherwise we would have never been in arrears [...]. If we are not repaying is because we cannot do it, not because we don't want to. I am not going to quit other repayments [such as another loan he had borrowed for his business]. I don't like it. But the mortgage, I can no longer face it because I cannot work as I used to [due to his illness]."

According to this reasoning, keeping up with repayments any longer only delays the problem, as the property will be certainly lost in the end, and, in the meantime, the great efforts made to avoid default may be preventing the satisfaction of other needs. This is the kind of argument usually transmitted in the meetings of the PAH: repaying a mortgage should not be prioritised over other basic expenses such as food, clothing, medicines, children's education, and the like. In an ironic way, Juan described what he had said in this regard to the director of the bank branch: "Look, I will tell you the order: my kids, my dog, my cat... You will be the last in the queue. When they are OK, you will be OK."

After a period of obsession with mortgage repayments, the decision to quit them can be experienced as liberation to a certain extent, as some room is made for a reorganisation of expenses. This can be so despite the threat of eviction, especially if debtors have access to information about what expects them next, and about the probable timing of the repossession process: if the right moves are made, actual eviction can be delayed for months of even for years. That is another crucial piece of information transmitted in the assemblies of the PAH, where many people arrive fearing immediate eviction and are made aware of the leeway they can rely on in order to figure out a housing alternative. 
At this point, it should also be taken into account that usually a household's financial vulnerability does not only derive from the burden of mortgage repayments, but also from other commitments related to other types of credit or to ordinary household expenses. As our ethnography shows, making the decision not to repay mortgages does not entail giving up other financial commitments, such as loans, electricity or water supply bills, or taxes. Mortgage repayments are then re-signified as the load that could not be born any more, the most unsustainable commitment, for which no support could be obtained on a regular basis, neither through social networks nor through public assistance.

Indeed, after the decision to quit repayments, household economies are reorganised - money is "juggled with" (Guérin, Morvant-Roux and Villarreal 2013) - and the remaining expenses to be faced every month may become more predictable, controllable and affordable. In this sense, in some cases, quitting repayments makes possible the fulfilment of other financial obligations that are perceived as more sustainable. For instance, Esteban could keep up with the repayments of an official loan he had borrowed to fund his firm, Juan could pay off his car, and Vanessa avoided to be in arrears with the loan she had used to cover her daughters' school enrolment and equipment.

The situation becomes then stabilised, at least until the next step of the repossession process. Some informants emphasize the contrast of this circumstance to the day-to-day uncertainties of everyday life under the pressure of mortgage repayments, when the satisfaction of pressing needs - including the need for food - had to be delayed as the mortgage was the absolute priority.

FINANCIAL VULNERABILITY:

GENERATING OLD AND NEW PATTERNS OF INEQUALITY?

The description of the Spanish mortgage crisis includes no doubt a number of elements that are common to other contexts where capitalist accumulation has been achieved at the expense of social majorities, and, more specifically, through the conversion not only of housing, but also of home-owners, into objects of financial exploitation (Aalbers 2008) or expropriation (Lapavitsas 2009). Parallelisms can be traced, for instance, with the foreclosures crisis in the US, where, "from 2007 to 2012, almost one American adult in twenty lost a home because of inability to afford the mortgage payments" (Martin and Niedt 2014: 5).

However, as some authors have described (López and Rodríguez 2010; Coq-Huelva 2013), the Spanish case offers some particularities. Among them, the fact that the historically-constructed aspiration to home-ownership among the working classes during the second half of the $20^{\text {th }}$ century was subsequently passed on to foreign immigrant workers during the last real-estate boom. In addition, the particularities of the Spanish mortgage law, especially regarding the persistence of outstanding debts after repossessions are completed, 
projects the financial vulnerability of households towards an indefinite future. In their seek for housing alternatives, they inescapably encounter another adverse scenario, that of the rental market, where the social stigmatisation of this housing tenure, along with the scarcity, high prices, legal dis-protection and bad condition of the rental housing stock tends to perpetuate uncertainty and the risk of residential exclusion.

In our view, several aspects should be highlighted regarding the contribution of the particular historical experience of the repossessions crisis to the reproduction of prior inequalities within the Spanish society.

There is no doubt that the social groups that have been affected most by home repossessions are those that have been traditionally excluded from wealth redistribution, such as the humblest fraction of the working classes. This is the case of many migrant workers who were forced to quit their projects of inclusion in the host society, which included the aspiration to become home owners. After the experience of repossessions, they have now landed again in a highly discriminative and informalised rental market - often on the basis of a sub-lease rather than as legal tenants.

But it may also be contended that the mortgage crisis also entails some novel aspects that, as time goes on, could reshape or at least qualify the patterns of inequality within the Spanish society.

To begin with, several thousands of households belonging to the working and middle classes, are facing indebtedness for life as a result of repossessions. As second life chances are denied to them, they are at risk of social exclusion, and of being confined to earn their livelihood in the informal economy: their condition as perpetual defaulters curtails their access to formal employment, to several forms of consumption, and even to certain sources of welfare provision, for example in the narrow domain of social housing. ${ }^{9}$ That is, for instance, what Esteban is experiencing. Although it seemed for a while that the hedge fund who currently owns the mortgage would let the family stay as tenants, the negotiation was suddenly interrupted. Now the auction of the flat has already taken place, and Esteban expects to be evicted in a few months' time. The family's prospects are bad, as their debt will remain after that, and they will only count on Esteban's disability pension, which is not compatible with a formal job in his former trade as a plumber. This will probably lead him

9 In this regard, in February 2015, a new law was passed to regulate non-judiciary agreements between debtors and creditors, in the aim of adapting repayments to the objective possibilities of debtors and, eventually, of cancelling the outstanding debt (see Real Decreto-Ley 1/2015, de 27 de Febrero, de Mecanismo de Segunda Oportunidad, Reducción de Carga Financiera y Otras Medidas de Orden Social). However, contrary to the expectations of one of the judges we interviewed, this legislation has not entailed a clear advantage for mortgage debtors up to now. The reasons for this lack of effectiveness would require further investigation. 
to work informally, with the consequent danger for his health and the precarisation of the future prospects to receive a decent retirement pension.

Besides, for the first time after the Civil War (1936-39), a breakdown in the pattern of material improvement from one generation to the next could occur. As our ethnography illustrates, the wave of repossessions has forced parents to support their adult children back, or even to accommodate them in their own homes, as they have been exposed to residential exclusion. In such cases, the parents' retirement pensions constitute the only stable source of income, in contrast to the uncertainties of paid work and the temporary nature of unemployment benefits. As a result, wide sectors of an increasingly dispossessed and precarious working class, in the face of long-term unemployment and of dropping incomes, have been forced to abandon their expectations to attain upward social mobility and a better standard of living than their parents'. Such expectations were typically observed during the housing bubble, as young couples moved from their parents' working-class neighbourhoods to higher-status residential areas. As it was Sonia's case, after the loss of their dwelling, these children of the working classes, now in their adulthood, were forced to move back to the areas where they had grown up, but they did it after a process of impoverishment, and with the sense of hopelessness to which their now chronic financial vulnerability has led.

Finally, the mortgage crisis has unveiled the expropriation and dispossession (Harvey 2007; Lapavitsas 2009) of the poor's economic and social capital by powerful actors, such as the building and real estate industry, alongside the banking sector, the two most prominent and established elites in Spain's recent history (Recio 2009). Indeed, through the financialisation of grass-roots economies founded on reciprocal bonds of obligation, social networks have been commodified and turned into economic profit for national and international capitalists and investors (Palomera 2014b). In this sense, it can be argued that the "chronification" of financial vulnerability seems to have taken a giant step that could be difficult to reverse. Indeed, during the past housing bubble in Spain, the poor were incorporated to the world of finance through the conversion of a basic resource, such as housing, into a financial asset (Aalbers 2008). But, beyond the important social implications of this process - that not only affects the ability to earn a livelihood, but also affects subjectivities and representations of well-being and success, as well as the sense of control over one's living conditions and life projects -, the financial products that give access to housing, mortgages, have in turn been the object of financialisation, setting the connection between the second and the fourth circuits of capital (Harvey 1978; Aalbers 2008). This financialisation may be contributing to the rise of some apparent paradoxes: for example, during the housing bubble, contrary to what happened before the deregulation of financial markets (Nasarre 2011), and mostly due to the securitisation of mortgages, credit institutions took the 
initiative to offer credit on a mass scale (Gregory 2012), and were interested in lending money to customers with high risks of insolvency. In a very counter-intuitive manner, borrowers who have a job or who are socially connected may find themselves trapped in the face of creditors, as their wages or other assets may be seized if they fail to meet repayments; while debtors who have no official sources of income, who lack social connections acting as guarantors in mortgage contracts, may get faster into arrears, reaching the point where creditors are prevented to keep on extracting wealth. In addition, as Azis (2016) has showed, employed - often working poor - defaulting debtors, as well as those with family responsibilities, lack the necessary time to join social movements or to devote themselves to negotiations with creditors, which may place them in a worse position to challenge their obligation to repay and, eventually, to have their debts cancelled. The actual consequences of such apparent paradoxes, and of the new logics of capital accumulation underlying them, might be contributing to the emergence of novel patterns of inequality that in some cases could be depicted as a "reversed inequality," and that should be the object of further consideration in the near future.

\section{REFERENCES}

AALBERS, Manuel B., 2008, "The financialization of home and the mortgage market crisis", Competition and Change, 12 (2): 148-166.

ALLEN, Judith, et al., 2004, Housing and Welfare in Southern Europe. Oxford, Blackwell.

AZIS, Georgios, 2016, "Rising up against the subordination of life in Barcelonès: an ethnography of the struggle of the afectadas for a future without debt chains", Uppsala, Uppsala Universitet, MA dissertation.

BOURDIEU, Pierre, 1979, "Les trois états du capital culturel”, Actes de la Recherche en Sciences Sociales, 30: 3-6.

BOURDIEU, Pierre, 1980, "Le capital social: notes provisoires", Actes de la Recherche en Sciences Sociales, 31: 2-3.

BOURDIEU, Pierre, 2001, Las Estructuras Sociales de la Economía. Buenos Aires, Manantial. COlAu, Ada, and Adrià AlEmANy, 2012, Vides Hipotecades: De la Bombolla Immobiliària al Dret a l'Habitatge. Barcelona, Angle Editorial.

COQ-HUELVA, Daniel, 2013, "Urbanisation and financialisation in the context of a rescaling State: the case of Spain”, Antipode, 45 (5): 1213-1231.

DUBOIS, Hans, and Robert ANDERSON, 2010, Managing Household Debts: Social Service Provision in the EU. Dublin, Eurofound Working Paper.

EUROPEAN COMMISSION, 2008, Towards a Common Operational European Definition of Overindebtedness. Brussels, European Commission, Directorate-General for Employment, Social Affairs and Equal Opportunities. 
EUROSTAT, 2012, "Over-indebtedness and financial exclusion statistics", available at $<$ http://ec.europa.eu/eurostat/statistics-explained/index.php/Archive:Over-indebtedness_and_financial_exclusion_statistics > (last access in February 2018).

FONDEVILlE, Nicole, Erhan ÖZDEMIR, and Terry WARD, 2010, Over-indebtedness: New Evidence from the EU-SILC Special Module, European Commission, Social Situation Observatory - Living Conditions and Income Distribution, November, Research Note 4/2010.

GARCÉS, Javier, and Alejandro SALCEDO, 2008, "Aspectos económicos, sociales y psicológicos del endeudamiento de los consumidores españoles", Estudios sobre Consumo, 83: 9-26.

GARCÍA-LAMARCA, Melissa, and Maria KAIKA, 2016, "'Mortgaged lives': the biopolitics of debt and housing financialization", Transactions of the Institute of British Geographers, 41: 313-327.

GEORGARAKOS, Dimitris, Adriana LOJSCHOVA, and Melanie WARD-WARMEDINGER, 2010, Mortgage Indebtedness and Household Financial Distress, Working Paper Series of the European Central Bank, n. 1156, February.

GRAEBER, David, 2011 , Debt, The First 5,000 years. New York, Melville House.

GREGORY, Chris A., 2012, "On money debt and morality: some reflections on the contribution of economic anthropology”, Social Anthropology, 20 (4): 380-396.

GUÉRIN, Isabelle, Solène MORVANT-ROUX, Magdalena VILLARREAL, 2013, Microfinance, Debt and Over-Indebtedness: Juggling with Money. London, Routledge.

HARVEY, David, 1978, “The urban process under capitalism: a framework for analysis", International Journal of Urban and Regional Research, 2 (1-3): 101-131.

HARVEY, David, 2007, El Nuevo Imperialismo. Madrid, Akal.

JEFFERSON, Anna, 2013, "Narratives of moral order in Michigan's foreclosure crisis", City and Society, 25 (1): 92-1 12.

LANGLEY, Peter, 2009, "Debt, discipline, and government: foreclosure and forbearance in the subprime mortgage crisis", Environment and Planning A, 41: 1404-1419.

LAPAVITSAS, Costas, 2009, "Financialised capitalism: crisis and financial expropriation", Historical Materialism, 17: 114-148.

LAZZARATO, Maurizio, 201 1, The Making of the Indebted Man: An Essay on the Neoliberal Condition. Los Angeles, Semiotext(e).

LÓPEZ, Isidro, and Emanuel RODRÍGUEZ, 2010, Fin de Ciclo: Financiarización, Territorio y Sociedad de Propietarios en la Onda Larga del Capitalismo Hispano (1959-2010). Madrid, Traficantes de Sueños.

MANGOT, Lluís, 2013, "La Plataforma de Afectados por la Hipoteca: de la crisis a la estafa, del Prozac al empoderamiento”, Clivatge, 2: 56-88.

MARTIN, Isaac W., and Christopher NIEDT, 2014, Foreclosed America. Stanford, Standford University Press.

MAUSS, Marcel, 1979 [1923-24], "Ensayo sobre los dones: razón y forma del cambio en las sociedades primitivas", in Marcel Mauss, Sociología y Antropología. Madrid, Tecnos, 155-263.

MIR, Jordi, et al., 2013, "Fundamentos de la Plataforma de Afectados por la Hipoteca: activismo, asesoramiento colectivo y desobediencia civil no violenta”, Educación Social, 55: 52-61.

NAREDO, José Manuel, 2009, "La cara oculta de la crisis: el fin del boom inmobiliario y sus consecuencias", Revista de Economía Crítica, 7: 313-340. 
NAREDO, José Manuel, and Antonio MONTIEL, 2011, El Modelo Inmobiliario Español. Barcelona, Icaria.

NASARRE, Sergio, 2011, "Malas prácticas bancarias en la actividad hipotecaria", Revista Crítica de Derecho Inmobiliario, 727: 2665-2737.

NASARRE, Sergio, 2014, "A legal perspective of the origin and the globalization of the current financial crisis and the resulting reforms in Spain", in Padraic Kenna (ed.), Contemporary Housing Issues in a Globalized World. Surrey, Ashgate, 37-72.

PALOMERA, Jaime, 2014a, "How did finance capital infiltrate the world of the urban poor? Homeownership and social fragmentation in a Spanish neighborhood", International Journal of Urban and Regional Research, 38 (1): 218-235.

PALOMERA, Jaime, 2014b, "Reciprocity, commodification and poverty in the era of financialization", Current Anthropology, 55 (9): 105-115.

RECIO, Albert, 2009, "Rasgos del nuevo poder oligárquico en España: viejas y nuevas caras de la oligarquía española”, in Fernando Aguilera and José Manuel Naredo (eds.), Economía, Poder y Megaproyectos. Madrid, Fundación César Manrique, 125-152.

ROSS, Andrew, 2014, Creditocracy, and the Case for Debt Refusal. OR Books.

SABATÉ, Irene, 2014, "Del país de los propietarios al país de los sobre-endeudados: reciprocidad, solidaridad y proyectos de transformación sistémica en tiempos de crisis", Ars \& Humanitas, 8 (1): 167-187.

SABATÉ, Irene, 2016, "Mortgage indebtedness and home repossessions as symptoms of the financialisation of housing provisioning in Spain", Critique of Anthropology, 36 (2): 197-211.

STOUT, Noelle, 2015, "Generating home", Cultural Anthropology (website), available at < http ://www.culanth.org/fieldsights/655-generating-home > (last access in February 2018).

STOUT, Noelle, 2016, "\#Indebted: disciplining the moral valence of mortgage debt online", Cultural Anthropology, 31 (1): 81-105.

SUÁREZ, Maka, 2014, "Movimientos sociales y buen vivir: ecuatorianos en la lucha por la vivienda en la plataforma de afectados por la hipoteca (PAH)", Revista de Antropología Experimental, 14 (6): $71-89$

TERRONES, Albert, 2013, "Segregation, housing market segmentation and the origin of over-indebtedness: the access to homeownership by foreign migrants based on over-indebtedness", paper presented at the 25th European Network for Hoursing Research Conference, Tarragona, June.

TORRES, Juan, 2010, La Crisis de las Hipotecas Basura. Madrid, Sequitur.

VALIÑO, Vanesa, 2014, "Mortgage foreclosure and housing rights in Spain: crisis or general deception?", in Padraic Kenna (ed.), Contemporary Housing Issues in a Globalized World. Surrey, Ashgate, 101-114.

YATES, Judith, and Vivienne MILLIGAN, 2007, Housing Affordability: A 21 st Century Problem, Melbourne, Australian Housing and Urban Research Institute Limited, AHURI Final Report No. 105, available at < https://www.ahuri.edu.au/research/final-reports/105> (last access in February 2018).

ZUNZUNEGUI, Fernando, 2013, "Over-indebtedness and mortgage lending”, Revista de Derecho Bancario y Bursátil, 129: 35-76. 